\title{
PÁRHUZAMOS KINEMATIKÁJÚ BILLENŐASZTAL ELEMZÉSE
}

\author{
Tüske István \\ PhD hallgató, Miskolci Egyetem, Szerszámgépek Intézeti Tanszéke \\ 3515 Miskolc, Miskolc-Egyetemváros, e-mail: istvantuske@googlemail.com \\ Hegedüs György \\ egyetemi docens, Miskolci Egyetem, Szerszámgépek Intézeti Tanszéke \\ 3515 Miskolc, Miskolc-Egyetemváros, e-mail: hegedus.gyorgy@uni-miskolc.hu
}

\begin{abstract}
Absztrakt
A korszerü öttengelyes marógépeket vizsgálva megállapitható, hogy a struktúra változatok különbözö felépitésü gépeket eredményeznek. Az adott változatokat elsösorban a gépen megmunkálható munkadarabok méretei és gép kinematikai felépitése határozzák meg. A gép kinematikai lánca alapján megkülönböztethetök a soros kinematikai, párhuzamos kinematikai és a hibrid kinematikai láncú változatok. A szimultán öttengelyes megmunkáláskor a szerszám és a munkadarab egymáshoz képest lineáris és orientációs mozgásokat végez egyidejüleg. Jelen cikkben egy párhuzamos kinematikai láncú billenöasztal változatának elemzését mutatjuk be.
\end{abstract}

Kulcsszavak: szerszámgépek, párhuzamos kinematika, mobilitási kritérium

\begin{abstract}
Examining modern five-axis milling machines, it can be concluded that the structural variants lead to machines with different constructions. The variants are mainly determined by the dimensions of the workpieces that can be manufactured on the machine and the kinematic structure of the machine. Based on the kinematic chain of the machine, a distinction can be made between serial kinematic, parallel kinematic and hybrid kinematic chain variants. On simultaneous five-axis machining, the tool and the workpiece perform linear and orientational movements relative to each other simultaneously. In this paper an analysis of variant of a tilting table with parallel kinematics is presented.
\end{abstract}

Keywords: machine tools, parallel kinematics, mobility criteria

\section{Bevezetés}

A klasszikus forgácsolási alapelvek szerint a marási technológiára jellemző, hogy a forgácsoló forgó főmozgást a szerszám, a mellékmozgásokat a munkadarab végzi. Ez az elv a hagyományos 2D-2,5D marási müveleteknél még megfigyelhető, azonban a 3D-5D-s megmunkálásoknál a lineáris $(X, Y, Z)$ és orientációs $(A, B)$ mozgásokat megosztják a szerszám és munkadarab között. A „mozgasd a kisebb tömeget"-elv figyelembe vételével a mozgásmegosztást célszerü olyan módon alkalmazni, hogy megmunkálás során a nagysebességü mozgásokat a jellemzően kisebb tömegü szerszám, az alacsony sebességü mozgást (pl. orientáció) a jellemzően nagyobb tömegü munkadarab végezze. A jelenleg elterjedt marógép struktúraváltozatokat vizsgálva többféle mozgásmegosztás terjedt el, amit befolyásol a gép kinematikai láncának felépítése, valamint az azon megmunkálható munkadarabok sokfélesége, tömege, méretei. A munkadarab mozgását megvalósító kinematikai lánc alapvetően kétféle típusba 
sorolható: soros kinematikai lánc és párhuzamos kinematikai lánc. A teljes gép felépítését tekintve azonban meg kell említenünk a hibrid kinematikai láncú gépstruktúra változatot is [1], [2], [11].

\subsection{Soros kinematikai láncú gépstruktúra}

A soros kinematikai láncú struktúrára jellemző a nyílt kinematikai mechanizmus. A mozgásmegosztásra több változat terjedt el, mint például a TTT-RR, és a TTR-TR (ahol $T$ a lineáris, $R$ a forgó mozgásra utal). Az adott tengelyek mentén történő lineáris elmozdulások, valamint a tengelyek körüli elfordulások lehetséges változatainak számát kombinatorikai számításokkal határozhatjuk meg. A korábban említett mozgásmegosztást, valamint a tengelyekre jellemző paramétereket figyelembe véve az előállítható változatok számát egy permutáció és egy ismétlés nélküli variáció szerint határozhatjuk meg. A TTT-RR mozgásmegosztásnál a lehetséges változatok száma a

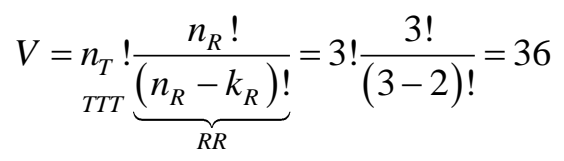

összefüggéssel határozható meg, ahol $n_{T}$ a lineáris tengelyek, $n_{R}$ a forgástengelyek számát, $k_{R}$ a kiválasztott forgástengelyek részhalmazának rendjét jelöli. Hasonlóan számítható a lehetséges változatok száma a TTR-TR mozgásmegosztásnál, így

$$
V=\underbrace{\frac{n_{T} !}{\left(n_{T}-k_{T}\right) !} \frac{n_{R} !}{\left(n_{R}-k_{R}\right)}}_{\text {TTR }} ! \underbrace{\frac{n_{T} !}{\left(n_{T}-k_{T}\right) !} \frac{n_{R} !}{\left(n_{R}-k_{R}\right) !}}_{T R}=\frac{3 !}{(3-2) !} \frac{3 !}{(3-1) !} \frac{1 !}{(1-1) !(2-1) !} \frac{2 !}{(26}
$$

adódik. Látható, hogy a képezhető változatok száma változatlan, azonban a szerszámgép változat morfológiailag egy eltérö felépítést eredményez.

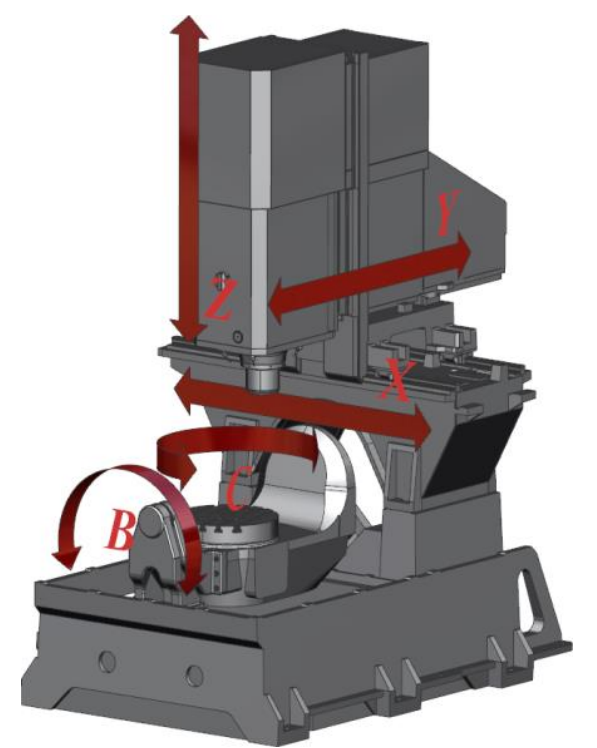

1. ábra. Haas UMC500 marógép modellje.

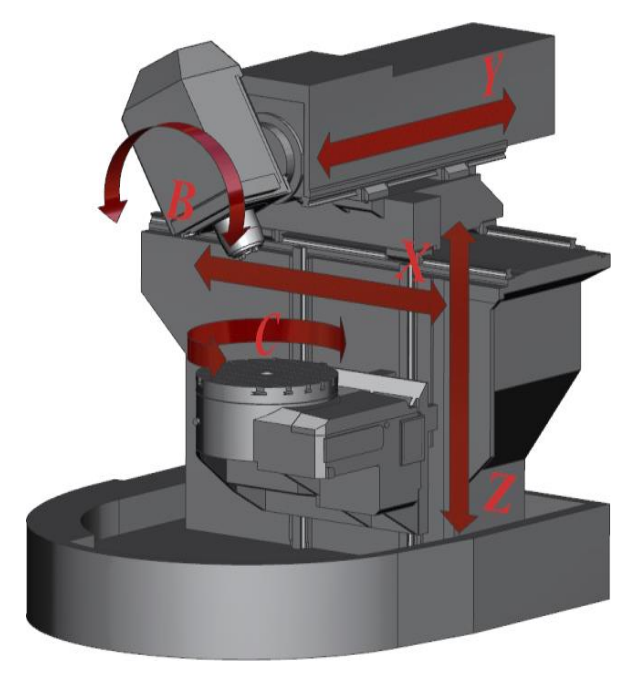

2. ábra. DMG DMU40 marógép modellje. 
A TTT-RR egy változatát mutatja az 1. ábra, míg a TTR-TR egy lehetséges változatát a 2. ábra szemlélteti. A gyakorlatban ilyen sokféle marógép változattal nem találkozunk, ennek okai lehetnek az adott változatra jellemző korlátok (pl. munkatér, üzemeltetés).

\subsection{Párhuzamos kinematikai láncú gépstruktúra}

A párhuzamos kinematikai láncú mechanizmusokra jellemző a zárt kinematikai lánc. További jellemzőjük a nagy sebesség és gyorsulás, hátrányuk a soros kinematikai láncú szerszámgépekkel összehasonlítva a kinematikai lánc kisebb merevsége, valamint a hasznos munkatér mérete [6]. Emiatt a párhuzamos kinematikájú mechanizmusokkal gyakran az ipari robotoknál találkozunk [3], [8]-[10].

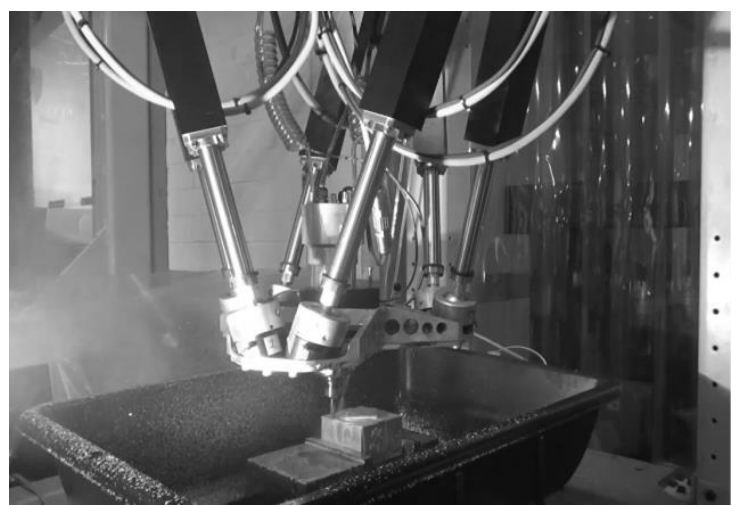

3. ábra. Föorsó (szerszám) mozgatás PKM [4].

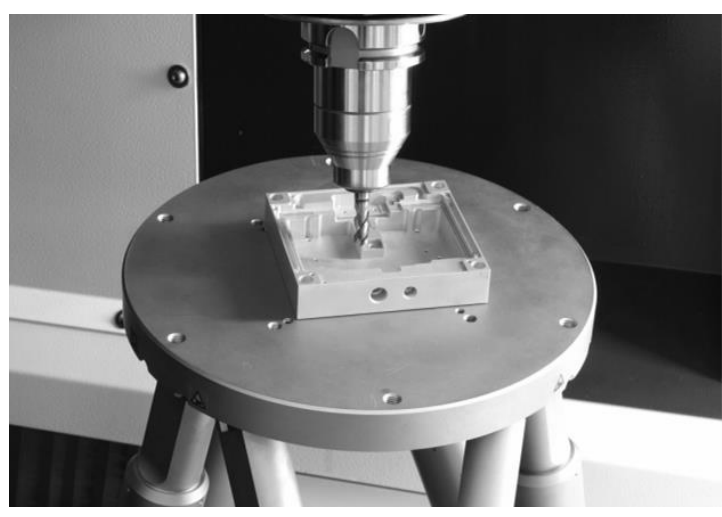

4. ábra. Munkadarab mozgatás (hexapod) [5].

A párhuzamos kinematikai láncú szerszámgépek körében is többféle megoldás terjedt el a munkadarab-szerszám mozgását figyelembe véve. A dinamikus mozgások következtében meghatározó a mozgatandó elem tömege, így nagy tömegủ munkadarabnál a kisebb tömegủ szerszámot mozgatják (3. ábra), ellenkező esetben célszerü a megmunkálandó elemet mozgatni (4. ábra). Párhuzamos kinematikájú gépeknél is megfigyelhető a mozgásmegosztás a hasznos munkatér növelése érdekében, azonban ezek a típusok a mozgásvezérlés bonyolultsága miatt nem terjedtek el.

\subsection{Hibrid kinematikai láncú szerszámgépek}

A hibrid kinematikai láncú szerszámgép egy párhuzamos és egy soros kinematikai lánccal rendelkező szerszámgéptípust jelent. Morfológiailag a leggyakrabban alkalmazott megoldás a párhuzamos kinematikai lánccal mozgatott platformra rögzített forgó-billenő fej (5. ábra).

Előfordulhat a párhuzamos és a soros kinematikai lánc szétválasztása, a főorsó-szerszám mozgatását a párhuzamos kinematikai lánc valósítja meg, a munkadarab orientációját egy soros kinematikájú billenő-forgó asztal (6. ábra). 


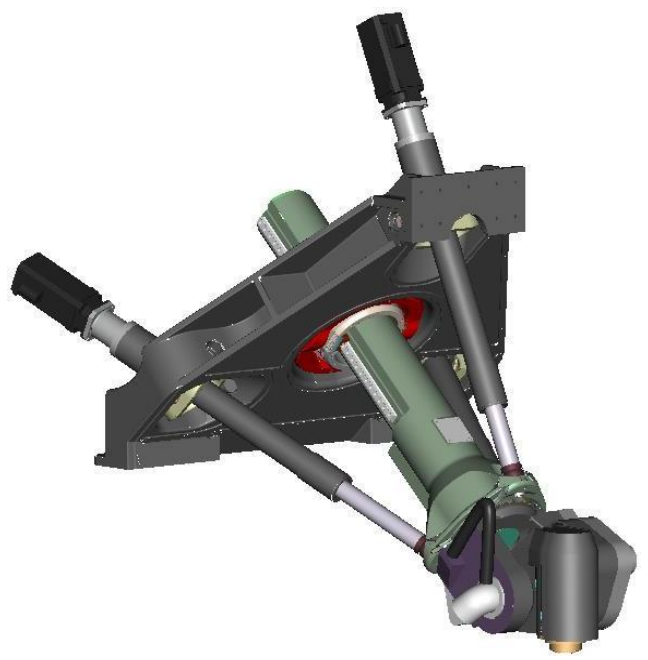

5. ábra. DTM100 hibrid megmunkálógép [6].

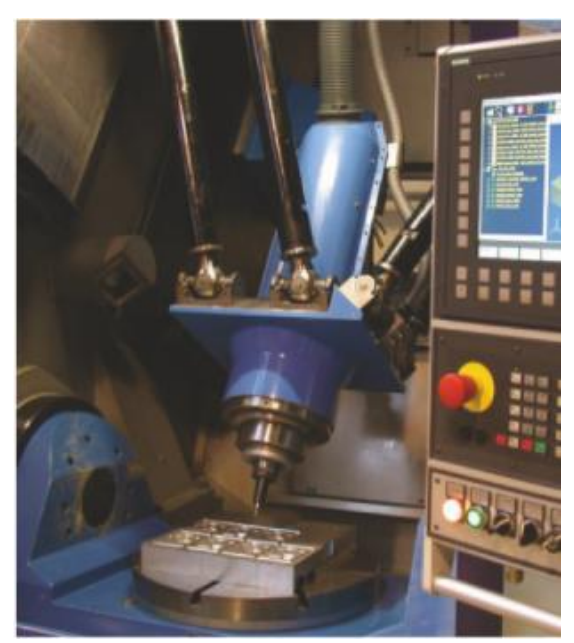

6. ábra. Fatronik VERNE megmunkálógép [7].

\section{Párhuzamos kinematikai láncú billenőasztal}

Az előző alfejezetekben láthattuk, hogy a szerszámgépek a kinematikai láncok alapján sokféle morfológiával rendelkeznek. Szimultán 5D-s megmunkálási műveletek a gyakorlatban sok esetben előfordulnak, ezekre a feladatokra a soros kinematikájú gépek a legelterjedtebbek, köszönhetően a munkadarabok változatos megjelenésének. A párhuzamos kinematikai láncú mechanizmusok elterjedése megfigyelhető manipulátoroknál is, melyek a szerszám vagy munkadarab nem forgácsoló mellékmozgásait valósítják meg. Bizonyos munkadaraboknál az orientációs mozgások csak szük tartományban változnak (pl. öntőszerszámok oldalferdesége), ekkor a párhuzamos kinematikai lánccal rendelkező egység munkatér korlátjaitól eltekinthetünk. Nagyobb tömegü munkadaraboknál, ahol nagy forgácsleválasztás és forgácsolási teljesítmény szükséges, a mozgasd a kisebb tömeget elv is megvalósulhat a mozgásmegosztáskor figyelembe véve a mozgatott egységek teljes tömegeit. Egy ilyen szerszámgép konstrukciót feltételezve a hibrid kinematikai láncú szerszámgépnek létezhet egy $T T T-R R$ változata, ahol a szerszám forgácsoló fömozgását és annak mellékmozgásait a soros TTT kinematikai lánc, míg a munkadarab orientációs mellékmozgásait az $R R$ párhuzamos kinematikai lánc végzi. Az ilyen kinematikai lánccal rendelkező billenőasztal vázlatát szemlélteti a 7. ábra.

A billenőasztal kinematikai láncában három darab $A_{i}(i=1 \ldots 3)$ jelölésủ aktív aktuátor foglal helyet. Az aktuátorok alsó bekötési pontjai a rögzített platformhoz a $K_{f, i}(i=1 \ldots 3)$, míg a felső bekötési pontjai a mozgó platformhoz a $K_{m, i}(i=1 \ldots 3)$ kardáncsuklókon keresztül történik. A $K_{k}$ rögzített központi kardáncsukló a mozgó platformhoz kötött. Az aktuátorok egyidejüleg lineáris és forgó mozgás megvalósítását teszik lehetővé az előírt munkadarab orientációnak megfelelően. 


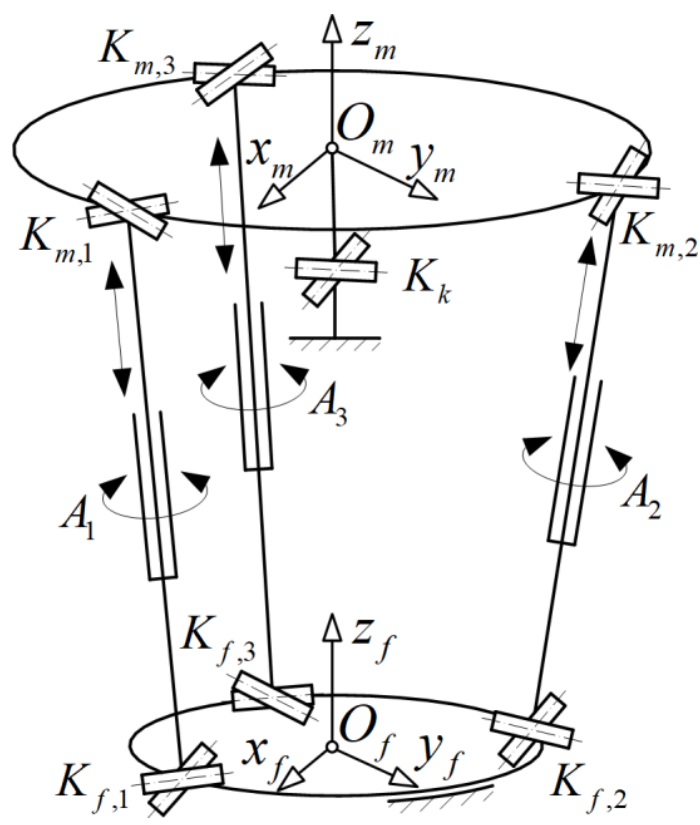

7. ábra. Központi kardáncsuklós billenőasztal kinematikai vázlata.

Az 1. táblázat tartalmazza a kinematikai lánc negyedosztályú kényszerei számát és elmozdulásokat.

1. táblázat. A kinematikai kényszerek szabadságfokainak száma.

\begin{tabular}{|c|c|c|}
\hline Jelölés & Kényszerek száma & Szabadságfokok száma \\
\hline$A_{i}(i=1 \ldots 3)$ & 1 & 2 (lineáris, forgó) \\
\hline$K_{f, i}(i=1 \ldots 3)$ & 1 & 2 (forgó, forgó) \\
\hline$K_{m, i}(i=1 \ldots 3)$ & 1 & 2 (forgó, forgó) \\
\hline$K_{k}$ & 1 & 2 (forgó, forgó) \\
\hline
\end{tabular}

A billenőasztal szabadságfokának számát a teljes kinematikai lánc kényszereinek ismeretében egy zárt párhuzamos kinematikai láncú mechanizmusnál a módosított Csebisev-Grübler-Kutzbach mobilitási kritérium

$$
M=\lambda(n-j-1)+\sum_{i=1}^{j} f_{i}-f_{p}
$$

alapján határozhatjuk meg. A (3) egyenletben $\lambda=6$ térbeli mechanizmusnál, $n$ a mechanizmus tagjainak, $j$ a mechanizmus kényszereinek a száma, $f_{i}$ az $i$. kényszer szabadságfokának, $f_{p}$ a passzív szabadságokoknak a száma. Az $A_{i}$ jelü aktuátorokban 2 tagot, valamint negyedosztályú kényszereket feltételezve, a rögzített és a mozgó platformot figyelembe véve tagok száma $n=8$, a kényszerek száma 
j=10 az 1. táblázat szerint. A kinematikai modell és (3) alapján a billenőasztal szabadságfokának száma

$$
\begin{gathered}
M=6(8-10-1)+(3 \cdot 2)+(3 \cdot 2)+(3 \cdot 2)+(1 \cdot 2)-0=2 \\
K_{f, i} \quad{ }_{A_{i}}{ }_{K_{m, i}}{ }_{K_{k}}
\end{gathered}
$$

adódik. Ha az egyes $A_{i}$ aktuátorokat, $K_{f, i}$ rögzített, $K_{m, i}$ mozgó és $K_{k}$ központi kardáncsuklókat ötödosztályú kényszerekre bontjuk, akkor az $A_{i}$ aktuátorokban 2 elemi kényszer 3 tagot, a kardáncsuklók az aktuátorokat, a rögzített, valamint a mozgó platformot kötik össze így a tagok száma $n=18$, a kényszerek száma $j=20$. Felhasználva a (3) egyenletet az eredmény

$$
M=6(18-20-1)+3 \cdot(6 \cdot 1)+(2 \cdot 1)-0=2
$$

változatlan. A fenti modell és a Csebisev-Grübler-Kutzbach mobilitási kritérium alapján látható, hogy a kényszerek számának csökkentése a szabadságfokok számát növeli, újabb kényszerek beépítése a kinematikai láncba a szabadságfokok számát redukálja és $M<0$ esetén a kinematikai lánc túlhatározottá válik. Fontos megjegyezni, hogy a mobilitási kritérium a mechanizmus geometriai méreteit, valamint elrendezését nem veszi figyelembe. Tételezzük fel, hogy a 7. ábra kinematikai modelljét oly módon változtatjuk, hogy az $A_{i}$ aktuátorok elrendezése olyan, ahol azok geometriai tengelyei a $K_{k}$ központi kardáncsukló egyik forgástengelyére illesztett síkban fekszenek (a négy tengely egy síkot határoz meg, geometriailag nem függetlenek). Belátható, hogy ekkor a billenőasztallal megvalósítható orientációs mozgások száma csökken. További hátránya a mobilitási kritériumnak, hogy kötött mozgású párhuzamos kinematikájú mechanizmusoknál nem minden esetben ad megbízható eredményt [12].

\section{3. Összefoglalás}

Jelen cikkben bemutattuk a különböző kinematikai lánccal rendelkező szerszámgépek néhány típusát. Megvizsgáltunk egy párhuzamos kinematikai lánccal rendelkező munkadarab orientációját megvalósító két szabadságfokú billenőasztalt a mobilitási kritérium szerint, azonban a mechanizmus alaposabb vizsgálatát célszerü elvégezni más módszerekkel is a mobilitási kritérium hátrányainak kiküszöbölésére.

\section{Köszönetnyilvánítás}

A cikkben ismertetett kutató munka az EFOP-3.6.1-16-2016-00011 jelü „Fiatalodó és Megújuló Egyetem - Innovatív Tudásváros - a Miskolci Egyetem intelligens szakosodást szolgáló intézményi fejlesztése" projekt részeként - a Széchenyi 2020 keretében - az Európai Unió támogatásával, az Európai Szociális Alap társfinanszírozásával valósul meg.

\section{Irodalom}

[1] Tlusty, J., Ziegert, J., Ridgeway, S.: Fundamental Comparison of the Use of Serial and Parallel Kinematics for Machines Tools, CIRP Annals, Vol.48 No.1 (1999), pp.351-356, ISSN 00078506, https://doi.org.10.1016/S0007-8506(07)63200-4

[2] Fassi, I., Wiens, G. J.: Multiaxis Machining: PKMs and Traditional Machining Centers, Journal of Manufacturing Processes, Vol.2 No.1 (2000), ISSN 1526-6125, pp.1-14, https://doi.org/10.1016/S1526-6125(00)70008-9 
[3] Merlet, J.-P.: Parallel Robots, Springer 2006, ISBN 978-1-4020-4132-7

[4] https://www.mikrolar.com/p1500

[5] https://www.pi-usa.us/en/tech-blog/precision-robotics-and-automation-hexapods-advanceproduction-processes/

[6] Pandilov, Z., Dukovski, V.: Parallel Kinematics Machine Tools: Overview - From History to The Future, Annals Of Faculty Engineering Hunedoara - International Journal of Engineering, Vol.10 No.2 (2012), ISSN: 2601-2332, pp.111-124

[7] Kanaan, D., Wenger, P., Chablat, D.: Kinematic analysis of a serial-parallel machine tool: The VERNE machine, Mechanism and Machine Theory, Vol.44 No.2 (2009), pp.487-498, ISSN 0094-114X, https://doi.org/10.1016/j.mechmachtheory.2008.03.002

[8] Pandilov, Z., Dukovski, V.: Comparison of The Characteristics Between Serial and Parallel Robots, Acta Technica Corviniensis - Bulletin of Engineering, Vol.7 No.1 (2014), ISSN: 2067 - 3809, pp.143-160

[9] Liu, X.-J., Wang, J.: Parallel Kinematics - Type, Kinematics, and Optimal Design, SpringerVerlag, 2014, ISBN 978-3-642-36928-5

[10] Zhang, D., Wei, B.: Dynamic Balancing of Mechanisms and Synthesizing of Parallel Robots, Springer, 2016, ISBN 978-3-319-17682-6, https://doi.org/10.1007/978-3-319-17683-3

[11] Kiss, R., Takács, Gy.: Szerszámgép struktúrák leirására alkalmas módszerek vizsgálata, Multidiszciplináris tudományok, 6. kötet 1 sz. (2016), ISSN 2062-9737, pp.

[12] J. H. Vargas R., O. A. Varela, Á. Valera: Geometric Analysis of a 3R-2T Low Mobility Parallel Robot, 2018 IEEE 2nd Colombian Conference on Robotics and Automation (CCRA), Barranquilla, 2018, pp. 1-7, https://doi.org/10.1109/CCRA.2018.8588154 